\section{Keterampilan Proses Sains Peserta Didik Kelas XI SMA Negeri 9 Maros Pada Mata Pelajaran Biologi yang Dibelajarkan dengan Model Discovery Learning}

\author{
Wulandari R \\ Yusminah Hala \\ Arsad Bahri
}

\begin{abstract}
Abstrak. Penelitian ini bertujuan untuk mengetahui keterampilan proses sains peserta didik pada pembelajaran discovey learning di kelas XI SMA Negeri 9 Maros. Penelitian ini termasuk penelitian deskriptif. Sampel dalam penelitian ini adalah peserta didik kelas XI MIPA 1 dengan jumlah siswa 35 orang. Data hasil penelitian diperoleh dengan lembar observasi keterampilan proses sains peserta didik. Teknik analisis data dengan analisis statistik deskriptif. Statistik deskriptif digunakan untuk mendeskripsikan keterampilan proses sains siswa. Hasil penelitian menunjukkan bahwa peningkatan rata-rata keterampilan proses sains siswa pada pertemuan pertama sebesar 66,50\% meningkat menjadi $75,07 \%$ pada pertemuan kedua, dan meningkat menjadi $81,11 \%$ pada pertemuan ketiga. dan berada pada kategori cukup hingga kategori baik. Kesimpulan dari penelitian ini adalah keterampilan proses sains kelas XI MIPA 1 SMAN 9 Maros dapat ditingkatkan melalui pembelajaran berbasis discovery learning

Kata Kunci: discovery learning, keterampilan proses sains
\end{abstract}

\section{Pendahuluan}

Pembelajaran merupakan proses interaksi antara peserta didik dengan pendidik dan sumber belajar pada suatu lingkungan belajar. Dalam proses pembelajaran, peserta didik dipandang sebagai individu yang unik dan berbeda antara satu dengan yang lainnya memiliki kemampuan berbeda seperti kemampuan akademik, minat, dan latar belakang (Palennari, 2011). Pembelajaran biologi merupakan pembelajaran yang menekankan untuk menemukan konsep pemahaman pada peserta didik melalui pengamatan langsung terhadap objek yang dipelajari. Karena itu, peserta didik perlu dibantu untuk mengembangkan sejumlah keterampilan proses agar mereka mampu menjelajahi dan memahami alam sekitar. Biologi sangat berkaitan erat dengan cara mencari tahu tentang alam secara sistematis, sehingga dalam mempelajari biologi tidak hanya mengajarkan materi atau hafalan biologi saja kepada peserta didik, tetapi juga dengan belajar biologi, peserta didik akan memperoleh pengalaman dalam menerapkan metode ilmiah melalui percobaan ataupun eksperimen. Keterampilan proses bertujuan untuk meningkatkan kemampuan anak didik menyadari, memahami dan menguasai rangkaian bentuk kegiatan yang berhubungan dengan hasil belajar yang telah dicapai peserta didik. Keterampilan proses sains sangat penting dikembangkan dalam pendidikan karena merupakan kompetensi dasar untuk mengembangkan sikap ilmiah siswa dan keterampilan dalam memecahkan masalah, sehingga dapat membentuk pribadi siswa yang kreatif, kritis, terbuka, inovatif, dan

\section{Biology Teaching and Learning}

p-ISSN 2621 - 5527

e-ISSN 2621 - 5535

Abstract. The objective of the study is to find out science process skills students on discovery learning in class XI of Senior High School 9 of Maros.

This study was descriptive research. The groups chosen as the study sample are XI MIPA 1 with number of students 35 people. The research data is observation of the student's science process skills. data analysis technique with descriptive statistics. Descriptive statistics are used to describe students' science process skills. The results showed that the average increase in students' science process skills at the first meeting was $66.50 \%$, increasing to

$75.07 \%$ at the second meeting, and increasing to $81.11 \%$ at the third meeting. and is in the category of sufficient to good category. The

conclusion of this research is the science process skills of grade XI MIPA

1 of SMAN 9 Maros can be improving

through based discovery learning. Keywords: discovery learning, science process skills.

Wulandari R

Universitas Negeri Makassar

Indonesia

Yusminah Hala

Universitas Negeri Makassar

Indonesia

Arsad Bahri

Universitas Negeri Makassar Indonesia 
dan kompetitif dalam persaingan pada dunia global masyarakat (Haryono, 2006).

Abungu (2014) mengungkapkan bahwa pengembangan keterampilan proses sains digunakan untuk membantu siswa memperoleh pemahaman materi yang lebih bersifat long term memory sehingga diharapkan mampu menyelesaikan segala bentuk permasalahan kehidupan sehari-hari terutama dalam menghadapi persaingan global. Meskipun demikian, kenyataan yang terjadi di dunia pendidikan, keterampilan proses sains belum dikembangkan di sekolah secara optimal. Rusmana (2009) mengungkapkan bahwa proses penyelenggaraan pendidikan di sekolah belum mengoptimalkan berbagai keterampilan yang dimiliki siswa, hal ini salah satunya disebabkan oleh pembelajaran yang masih bersifat umum dan teoritik serta kurang menuntut siswa untuk menggunakan alat-alat pikirnya (tool-lessthought), sementara di masyarakat siswa dituntut untuk mampu menggunakan keterampilan secara optimal.

Mengingat pentingnya pengaruh keterampilan proses sains tersebut, maka diperlukan model pembelajaran yang dapat memfasilitasi terselenggaranya kegiatan pembelajaran yang mampu mengembangkan keterampilan proses sains siswa. Salah satu model pembelajaran yaitu dengan menggunakan model discovery learning. Model pembelajaran discovery learning yaitu belajar untuk menemukan, dimana peserta didik dihadapkan dengan suatu masalah atau situasi yang tampaknya ganjil sehingga peserta didik dapat memberi jalan pemecahannya (Markaban, 2008). Penerapan model pembelajaran discovery learning dapat menumbuh kembangkan keterampilan proses sains pada diri siswa. Kegiatan identifikasi masalah pada pada salah satu sintaks discovery learning dapat melatih siswa lebih aktif berpartisipasi dalam pembelajaran sehingga siswa dapat diberikan kesempatan untuk menggunakan keterampilan proses sainsnya. Menurut Akinbobola (2010) yang menyatakan bahwa model discovery learning sebaiknya digunakan oleh guru untuk mengembangkan keterampilan proses sains peserta didik

Berdasarkan latar belakang yang telah diuraikan di atas, maka rumusan masalah dalam penelitian ini adalah: Bagaimana keterampilan proses sains peserta didik pada pembelajaran discovery learning di kelas XI SMA Negeri 9 Maros?, Berdasarkan rumusan masalah di atas, maka tujuan dari penelitian ini adalah: untuk mengetahui keterampilan proses sains peserta didik pada pembelajaran discovery learning di kelas XI SMA Negeri 9 Maros.

\section{Metode Penelitian}

Penelitian ini adalah penelitian deskriptif yang menggambarkan keterampilan proses sains peserta didik pada pembelajaran inkuiri terbimbing. Penelitian ini dilaksanakan di SMA Negeri 9 Maros pada bulan oktober semester ganjil Tahun Ajaran 2019/2020. Sampel dalam penelitian ini adalah peserta didik kelas XI MIPA 1 dengan jumlah siswa 35 orang. Variabel bebas dalam penelitian ini adalah model pembelajaran discovery learning dan variabel terikat adalah keterampilan proses sains.

Teknik pengumpulan data yang digunakan dalam penelitian ini adalah lembar observasi berdasarkan rubrik penilaian, dengan mengacu pada indikator keterampilan proses sains. .Teknik analisis data yang digunakan yaitu analisis statistik deskripstif. 


\section{Hasil dan Pembahasan}

Tabel 1. Rata-rata Skor Capaian Tiap Aspek Keterampilan Proses Sains

\begin{tabular}{|c|c|c|c|c|}
\hline \multirow{2}{*}{$\begin{array}{c}\text { Aspek Keterampilan } \\
\text { Proses Sains }\end{array}$} & \multicolumn{3}{|c|}{ Capaian aspek } & Rata- \\
\cline { 2 - 4 } & Pertemuan 1 & Pertemuan 2 & Pertemuan 3 & \\
\hline Mengamati & 66.67 & 80.95 & 88.57 & 78.73 \\
\hline Menafsirkan pengamatan & 65,71 & 73.33 & 78.10 & 72.38 \\
\hline Berhipotesis & 61.90 & 69.52 & 76.19 & 69.20 \\
\hline Merencanakan percobaan & 71.43 & 80.95 & 85.71 & 79.36 \\
\hline Menerapkan konsep & 67.62 & 73.33 & 79.05 & 73.33 \\
\hline Berkomunikasi & 65.71 & 72.38 & 79.05 & 72.38 \\
\hline
\end{tabular}

Tabel 1 menunjukkan capaian skor tiap aspek maupun skor rata-rata keseluruhan aspek keterampilan proses sains dari pertemuan 1, pertemuan 2 dan pertemuan 3. Skor tersebut menunjukkan adanya peningkatan keterampilan proses sains pada setiap pertemuan. Peningkatan skor terjadi pada setiap aspek maupun rata-rata skor capaian aspek keterampilan proses sains. Berdasarkan Tabel 1 dapat dilihat tingkat kenaikan skor tiap aspek keterampilan proses sains yang disajikan dalam bentuk diagram pada gambar 1

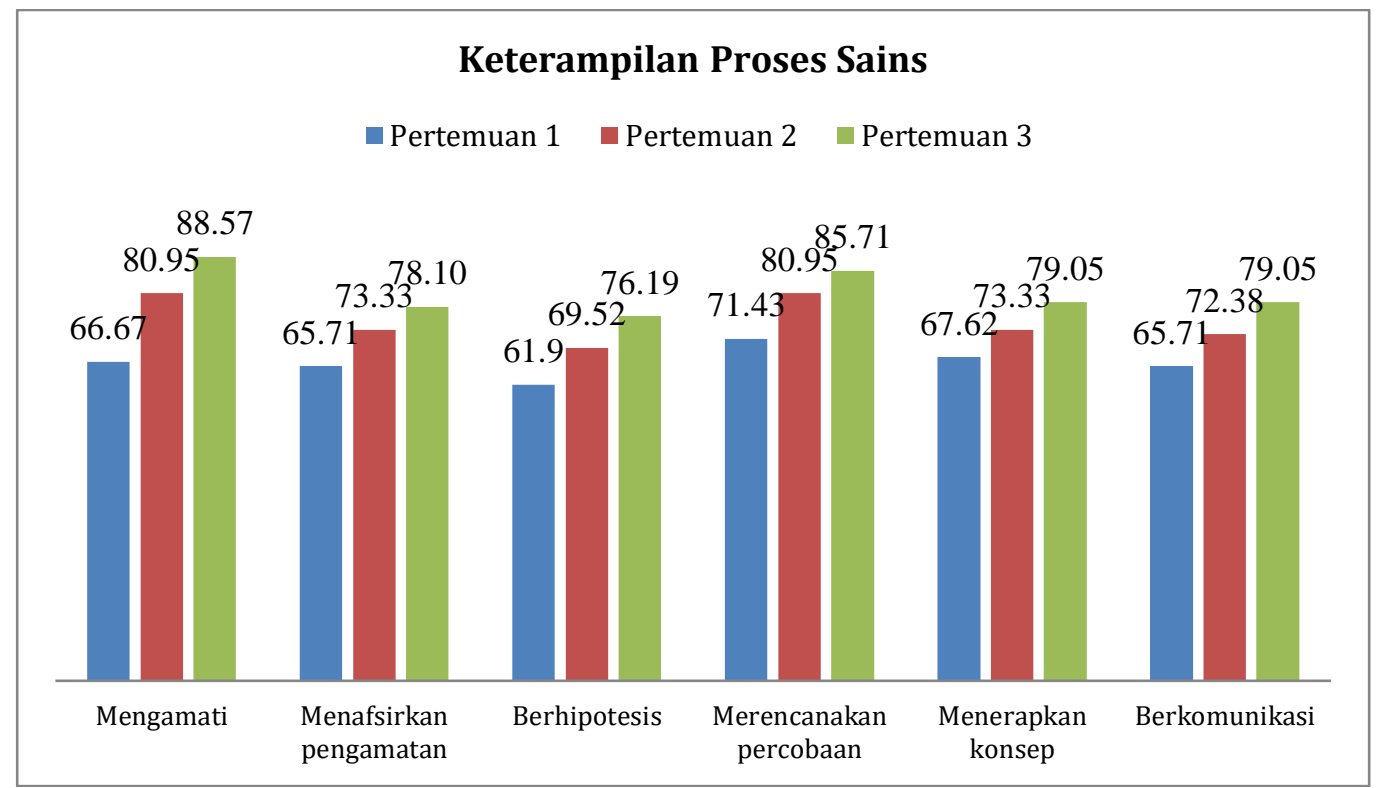

Gambar 1 Diagram Observasi Keterampilan Proses Sains Siswa

Berdasarkan Gambar 1 di atas menunjukkan bahwa setiap aspek keterampilan proses sains siswa dalam pembelajaran yang dilakukan oleh pengamat mempunyai persentase yang beragam, dimana pada setiap pertemuan menujukkan perubahan yang semakin baik yaitu pada aspek mengamati pertemuan pertama dengan persentase sebesar $66,67 \%$, pertemuan kedua sebesar $80,95 \%$, pertemuan ketiga sebesar $88.75 \%$. Hasil persentase tersebut menunjukkan bahwa hampir seluruh siswa terampil dalam hal "mengamati". Hasil analisis aspek KPS Menafsirkan pengamatan yaitu pada pertemuan pertama dengan persentase sebesar $65,71 \%$, pertemuan kedua sebesar 73,33\%, dan pertemuan ketiga sebesar 78,10\%. Hasil Persentase 
tersebut menujukkan bahwa siswa terampil dalam menafsirkan data hasil pengamatan. Hasil analisis KPS aspek berhipotesis yaitu pada pertemuan pertama dengan persentase sebesar $61,90 \%$, pertemuan kedua sebesar 69,52\%, dan pertemuan ketiga sebesar 76,19\%. Hasil persentase tersebut menunjukan bahwa kemampuan siswa dalam menemukan jawaban sementara atas permasalahan yang ada cukup terampil.

Hasil analisis aspek merencanakan percobaan diperoleh persentase pada pertemuan pertama sebesar $71,43 \%$, pertemuan kedua sebesar $80,95 \%$, dan pada pertemuan ketiga sebesar $85,71 \%$. Aspek menerapkan konsep pada pertemuan pertama dengan persentase sebesar 67,62\%, pertemuan kedua mendapatkan prsentase sebesar 73,33\%, dan pertemuan ketiga sebesar 79,05\%. Selanjutnya aspek KPS yang terakhir yaitu berkomunikasi diperoleh persentase pada pertemuan pertama sebesar $65,71 \%$, pertemuan kedua sebesar $72,38 \%$, dan pertemuan ketiga sebesar 79,05\%. Hasil persentase pada aspek berkomunikasi menunjukkan siswa cukup terampil.

Berdasarkan penjelasan diatas aspek keterampilan proses sains siswa persentase yang tertinggi yaitu aspek mengamati. Hal ini disebabkan karena keterampilan mengamati ini merupakan kemampuan dasar siswa yang sering dilakukan dalam kehidupan sehari-hari. Melalui kegiatan mengamati menimbulkan rasa ingin tahu siswa untuk penyelidikan terkait permasalahan yang telah diberikan. Siswa mengamati objek-objek dan fenomena alam dengan indera penglihatan, pendengaran, peraba, pembau, serta pengecap. Sehingga semua siswa senang melakukan kegiatan mengamati karena tumbuh rasa ingin tahu. Dan aspek yang terendah yaitu aspek berhipotesis, siswa belum mampu dan masih bingung untuk merumuskan kalimat yang tepat untuk sebuah hipotesis, sehingga siswa masih susah membuat jawaban sementara atas masalah yang disajikan, hal tersebut dikarenakan karena kurangnya pengetahuan awal siswa mengenai hipotesis.

\section{Pembahasan}

Keterampilan proses sains yang paling tinggi pada kelompok yang diajarkan dengan model pembelajaran discovery learning terdapat pada keterampilan mengamati dengan skor pada pertemuan ketiga $88,57 \%$ Hal ini disebabkan karena keterampilan mengamati ini merupakan kemampuan dasar siswa yang sering dilakukan dalam kehidupan sehari-hari. Melalui kegiatan mengamati menimbulkan rasa ingin tahu siswa untuk penyelidikan terkait permasalahan yang telah diberikan. Siswa mengamati objek-objek dan fenomena alam dengan indera penglihatan, pendengaran, peraba, pembau, serta pengecap. Sehingga semua siswa senang melakukan kegiatan mengamati karena tumbuh rasa ingin tahu sedangkan keterampilan proses sains paling rendah yaitu keterampilan berhipotesis dengan skor pada pertemuan ketiga 76,19\% Hal ini dikarenakan, siswa belum mampu dan masih bingung untuk merumuskan kalimat yang tepat untuk sebuah hipotesis, sehingga siswa masih susah membuat jawaban sementara atas masalah yang disajikan, hal tersebut dikarenakan karena kurangnya pengetahuan awal siswa mengenai hipotesis.

Dari hasil penelitian yang diperoleh dapat diketahui bahwa terdapat peningkatan keterampilan proses sains setiap pertemuan pada kelas yang dibelajarkan dengan model pembelajaran discovery learning. Hal ini sesuai dengan pendapat Akinbobola (2010) yang menyatakan bahwa model discovery learning sebaiknya digunakan oleh guru untuk mengembangkan keterampilan proses sains peserta didik. Penjelasan lebih lanjut tentang discovery learning sesuai yang tercantum dalam Permendikbud pada lampiran III adalah model pembelajaran discovery learning mengarahkan peserta didik untuk memahami konsep, arti, dan hubungan, melalui proses intuitif untuk akhirnya sampai kepada suatu kesimpulan. Hal tersebut terjadi bila peserta didik terlibat, terutama dalam penggunaan proses mentalnya untuk menemukan beberapa konsep dan prinsip. Penerapan model pembelajaran discovery learning dapat menumbuh kembangkan keterampilan proses sains pada diri siswa. Keterampilan proses 
(hlm. 132-137)

sains dengan menggunakan model discovery learning dilakukan melalui kegiatan penyelidikan dan pengamatan. Sejalan dengan hal tersebut, Kemendikbud (2013) menyatakan bahwa, langkah-langkah kegiatan penyelidikan discovery learning antara lain 1) stimulasi, 2) identifikasi masalah, 3) pengumpulan data, 4) pengolahan data, 5) pembuktian dan 6) penarikan kesimpulan. Keterampilan proses sains pada saat pembelajaran berlangsung menunjukkan bahwa model discovery learning melibatkan peserta didik unuk aktif dalam pembelajaran. Semua sintaks dalam model pembelajaran discovery learning dapat melatih siswa dalam menggunakan keterampilan proses sainsnya. Menurut Rachayuni (2016) pembelajaran discovery learning sangat penting karena dapat mengoptimalkan keterlibatan peserta didik secara langsung dalam pembelajaran dan membantu peserta didik memperoleh keterampilan proses sains melalui kegiatan ilmiah

Aktivitas pembelajaran pada kelas yang diajarkan dengan menerapkan model pembelajaran discovery learning terlihat lebih aktif dan mandiri karena pembelajaran berpusat pada siswa. Menurut Ilahi (2012) bahwa pembelajaran model discovery learning melibatkan langsung mental dan fisik peserta didik, melatih kemampuan berpikir melalui analisis dan pengkajian dalam memecahkan permasalahan. Hal ini akan melatih peserta didik untuk memiliki keterampilan proses sains. Keterampilan proses sains siswa perlu dilatih terusmenerus dengan menggunakan model pembelajaran yang tepat, sehingga dibutuhkan peranan guru dalam pemilihan model pembelajaran yang mampu melatih keterampilan proses sains. Menurut Yuniastuti (2013) keterampilan proses sains perlu dilatih dan dikembangkan dalam pembelajaran sains karena KPS mempunyai peranan, antara lain membantu peserta didik mengembangkan pikirannya, meningkatkan daya ingat peserta didik serta dapat membantu peserta didik mempelajari dan memahami konsep-konsep sains yang rumit dan abstrak.

Berdasarkan hasil observasi keterampilan proses sains siswa pada saat pembelajaran berlangsung menunjukkan bahwa model pembelajaran discovery learning melibatkan siswa untuk aktif dalam pembelajaran, khususnya keterampilan proses sains. Menurut Rachayuni (2016) yang menyatakan bahwa model pembelajaran discovery learning memberikan pengaruh positif terhadap peningkatan keterampilan proses sains peserta didik, karena discovery memungkinkan peserta didik terlibat langsung dalam kegiatan pembelajaran, belajar mengorganisasi dan menghadapi permasalahan, mampu memecahkan masalah dan menarik kesimpulan dari permasalahan yang dipelajari.Hal ini sesuai dengan hasil penelitian yang dilakukan Dewi (2008) bahwa pembelajaran biologi menggunakan model discovery learning terbukti telah meningkatkan keterampilan proses sains siswa. Hal ini dikarenakan pada model discovery learning terdapat tahapan-tahapan (sintaks) yang mendukung aspek keterampilan proses sains, seperti simulation yaitu siswa mengidentifikasi macam-macam struktur dan bentuk berbagai macam jaaringan hewan menggunakan awetan preparat, problem statement yaitu siswa membuat hipotesis eksperimen, data collecting siswa melakukan eksperimen untuk membuktikan hipotesis yang sudah dibuat sebelumnya dan verification dimana siswa menarik kesimpulan hasil eksperimen yang telah dilakukan. Pembelajaran biologi menggunakan model discovery sudah sesuai dengan hakikat sains yang mengutamakan aspek proses dan produk.

\section{Kesimpulan}

Berdasarkan hasil penelitian, dapat disimpulkan bahwa terdapat peningkatan keterampilan proses sains peserta didik pada pembelajaran discovery learning di kelas XI SMA Negeri 9 Maros.

\section{Referensi}

Abungu, H.E., Okere, M.I.O., \& wachanga, S.M. (2014). The Effect Of Science Process Skills Teaching Approach On Secondary School Students' Achievement In Chemistry In Nyado District, Kenya. Journal of Educational and Social Research. 4(6), 359-372. 
Akinbobola, A. O \& Folashade, A. (2010). Constructivist practices through guided discovery approach: The effect on students' cognitive achievement in Nigerian senior secondary school physics. Eurasian Journal of Physics and Chemistry Education 2(1), 16-18.

Dewi, Y. P. (2008). Keterampilan Proses Sains dan Retensi Siswa Pada Pembelajaran Subkonsep Alat Indera Melalui Pendekatan Guided Discovery di SMA Negeri 9 Bandung. Tidak dipublikasikan. Bandung: Universitas Pendidikan Indonesia.

Haryono. 2006. Model Pembelajaran Berbasis Peningkatan Keterampilan Proses Sains. Jurnal Pendidikan Dasar. 7 (1), 2-3.

Illahi, M. T. (2012). Pembelajaran Discovery Strategi dan Mental Vocational Skill. Yogyakarta: Diva Press

Kementerian Pendidikan dan Kebudayaan. (2013). Badan Pengembangan Sumber Daya Manusia Pendidikan dan Kebudayaan dan Penjaminan Mutu Pendidikan tentang Model Pembelajaran Penemuan (Discovery Learning). Jakarta. Kementerian Pendidikan Nasional.

Markaban. (2008). Model Pembelajaran Matematika dengan Pendekatan Penemuan Terbimbing. Yogyakarta: Departemen Pendidikan Nasional Pusat Pengembangan dan Pemberdayaan Pendidik dan Tenaga Kependidikan Matematika.

Palennari, M. (2011). Potensi Strategi Integrasi Pbl Dengan Pembelajaran Kooperatif Jigsaw Dalam Meningkatkan Pemahaman Konsep Mahasiswa. Jurnal Ilmiah Pendidikan, Biologi Edukasi, 3(2), 26-33.

Rachyuni. (2016). Meningkatkan Keterampilan Proses Sains dan Hasil Belajar IPA Melalui Penerapan Model Guided Discovery Di Kelas VII-I SMPN 32 Semarang. Jurnal Scientia Indonesia.1(1). 2-3

Rusmana, Nandang. (2009). Bimbingan dan Konseling Kelompok Di Sekolah (Metode, Teknik dan Aplikasi). Bandung. Rizqi Press.

Yuniastuti, E. (2013). Peningkatan Keterampilan Proses, Motivasi, dan Hasil Belajar Biologi dengan Strategi Pembelajaran Inkuiri Terbimbing pada Siswa Kelas VII SMP Kartika V-1 Balikpapan. Prosiding Seminar Nasional Sains Dan Teknologi, ISSN 1412-565, 80-82.

\begin{tabular}{|l|l|}
\hline Wulandari $R$ & $\begin{array}{l}\text { S.Pd, Jurusan Biologi, Fakultas Matematika dan Ilmu } \\
\text { Pengetahuan Alam, Universitas Negeri Makassar } \\
\text { Email: wulan4462@gmail.com }\end{array}$ \\
\hline Yusminah Hala & $\begin{array}{l}\text { Ir, M.S, Dr, Professor, Dosen Jurusan Biologi, Fakultas } \\
\text { Matematika dan Ilmu Pengetahuan Alam, Universitas Negeri } \\
\text { Makassar } \\
\text { Email: yushala12@gmail.com }\end{array}$ \\
\hline Arsad Bahri & $\begin{array}{l}\text { M.Pd, Dr. Dosen Jurusan Biologi, Fakultas Matematika dan } \\
\text { Ilmu Pengetahuan Alam, Universitas Negeri Makassar } \\
\text { Email: arsad.bahri@unm.ac.id }\end{array}$ \\
\hline
\end{tabular}

